\title{
Development of Improved Biogas Plant for Biomethanation of Spent Mushroom Substrate and Cow Dung
}

\author{
Pradip Narale $^{1^{*}}$, Surendra Kothari ${ }^{2}$ and Nafisa Ali ${ }^{2}$
}

${ }^{1}$ ICAR-AICRP on EAAI, Central Institute of Agricultural Engineering, Nabi Bagh, Berasia Road, Bhopal-462038 (MP), India

${ }^{2}$ Department of Renewable Energy Engineering, College of Technology and Engineering, Maharana Pratap University of Agricultural and Technology, Udaipur-313001

(Rajasthan), India

*Corresponding author

\section{A B S T R A C T}

\begin{tabular}{|c|c|}
\hline Keyw & \multirow{4}{*}{$\begin{array}{l}\text { Biogas plant of } 2 \mathrm{~m}^{3} \text { was developed for the codigestion of } 25 \% \text { SpBMS }+75 \% \text { cow dung } \\
\text { substrate. The dome has provided with additional stirring mechanism to break the scum } \\
\text { formation inside digester. The developed plant was further evaluated continuously for } 80 \\
\text { days by daily feeding a mixture of } 12.5 \mathrm{~kg} \text { of spent button mushroom substrate and } 37.5 \mathrm{~kg} \\
\text { of fresh cow dung with } 100 \mathrm{~kg} \text { of water. } 100 \mathrm{~kg} \text { of water with } 50 \mathrm{~kg} \text { of selected substrate } \\
\text { ( } 12.5 \mathrm{~kg} \text { SpBMS }+37.5 \mathrm{~kg} \text { cow dung) was mixed daily to maintain } 10 \% \text { solid content of } \\
\text { material. The hydraulic retention time (HRT) of the modified biogas plant was } 40 \text { days, so } \\
\text { the observations of produced biogas were recorded daily throughout two cycles of HRT } \\
\text { ( } 80 \text { days). The observations were recorded from } 4^{\text {th }} \text { February, } 2016 \text { to } 23^{\text {rd }} \text { April, } 2016 \text {. } \\
\text { The average daily biogas production during } 80 \text { days of biomethanation period was } \\
\text { observed as } 1.852 \mathrm{~m}^{3} / \text { day. }\end{array}$} \\
\hline & \\
\hline & \\
\hline & \\
\hline
\end{tabular}

\section{Introduction}

Biomethanation is production of biogas through anaerobic digestion of spent mushroom substrate. Anaerobic digestion is a series of biological processes in which microorganisms break down biodegradable material in the absence of oxygen and produces biogas (Lin et al., 2014). Spent mushroom substrate is a byproduct of mushroom cultivation technique. It is the organic substrate material left over after harvesting of mushroom (Mehta et al., 1990).
It is different from typically available dry leafy biomass. Spent mushroom substrate cannot be utilized directly without sterilization for animal feeding like dry leafy biomass (Wendi et al., 2014).

It was estimated that for one $\mathrm{kg}$ production of mushroom around $5 \mathrm{~kg}$ of spent mushroom substrate produced (Bisaria et al., 1983, Kumari et al., 2013). This huge quantity of spent mushroom substrate was not utilized most of the time and may be either buried openly in the environment or composted to 
prepare enriched organic manure. Open burning of spent mushroom substrate can cause emission of harmful greenhouse gases in the environment which may results in to global warming and climate change effects. Composting of organic manure take a long time to convert organic material in to enriched fertilizer and may create unhygienic surrounding condition. During the process of composting carbon dioxide $\left(\mathrm{CO}_{2}\right)$, methane $\left(\mathrm{CH}_{4}\right)$, nitrous oxide $\left(\mathrm{N}_{2} \mathrm{O}\right)$ is released in to the environment (Fleming et al., 2006).

These untapped greenhouse gases stays in the atmosphere for longer duration and contributes heavily in global warming of the earth. Therefore biomethanation study of spent mushroom substrate provides an important role to utilized methane produced through anaerobic digestion and enriched organic solid-liquid fertilizer for agriculture production (Deublein and Steinhauser, 2008).

\section{Materials and Methods}

The various parameters used in designing of biogas plant were as follows,

$\mathrm{W}=$ Weight of waste/substrate fed per day (kg/day)

$\mathrm{G}=$ Gas production rate $\left(\mathrm{m}^{3} /\right.$ day $)$

$\mathrm{V}_{\mathrm{s}}=$ Active slurry volume in the digester $\left(\mathrm{m}^{3}\right)$

$\mathrm{V}_{\mathrm{d}}=$ Dome volume $\left(\mathrm{m}^{3}\right)$

$\mathrm{H}=$ Height of cylindrical portion of the digester up to the top edge of the outlet opening (m)

$\mathrm{D}=$ Diameter of the digester $(\mathrm{m})$

$\mathrm{d}_{\mathrm{h}}=$ Height of the dome $(\mathrm{m})$

$\mathrm{r}=$ radius of the dome $(\mathrm{m})$
Various design parameters can be estimated with the help of following equation

\section{Gas production rate $(G)$}

From lab study it was found that $0.2 \mathrm{~kg}$ of undigested mixture of spent button mushroom substrate and cow dung (25\% SpBMS $+75 \%$ Cow dung) can produce $7.183 \mathrm{~L}$ of biogas.

Therefore from $50 \mathrm{~kg}$ of this substrate when mixed with $100 \mathrm{~kg}$ of water will generate approximately around $1.795 \mathrm{~m}^{3}$ of biogas production.

$\mathrm{G}=1.795 \mathrm{~m}^{3} /$ day

Active slurry volume Vs: Vs which is related to the HRT can be determined by following equation,

$V s=H R T *\left[\frac{W_{s b}}{\rho_{s b}}+\frac{W_{w}}{\rho_{w}}\right]$

Whereas, $\mathrm{W}_{\mathrm{sb}}$ is weight of substrate $50 \mathrm{~kg}$, $\mathrm{Ww}$ is weight of water mixed with substrate $100 \mathrm{~kg}, \rho_{\mathrm{sb}}$ is the density of substrate 2325 $\mathrm{kg} / \mathrm{m}^{3}$, and $\rho \mathrm{w}$ is the density of water 1000 $\mathrm{kg} / \mathrm{m}^{3}$.

Considering 40 days of HRT period and 50 $\mathrm{kg} /$ day of substrate feeding along with $100 \mathrm{~kg}$ of water,

$\mathrm{V}_{\mathrm{s}}=4.86 \mathrm{~m}^{3}$

\section{Estimation of height and diameter of digester}

For a cylindrical shaped digester of diameter (D) and height $(\mathrm{H})$ requisite volume of the digester was calculated using following equation. Knowing the active slurry volume from the previous equation, $\mathrm{H}$ was determined from the following equation, 
$(\Pi / 4) \mathrm{D}^{2} \cdot \mathrm{H}=\mathrm{V}_{\mathrm{s}}$

Considering cylindrical shaped digester with diameter (D) to depth or height $(\mathrm{H})$ ratio as $1: 2.5$.

$(\Pi / 4) \mathrm{D}^{2} . \mathrm{H}=4.86$

(П/4) $\mathrm{D}^{2}$. 3.4=4.86 (*Assuming height $\mathrm{H}=3.4$ $\mathrm{m})$

$\mathrm{D}=1.35 \mathrm{~m}$

\section{Estimation of gas holder size/ dome volume}

Based on the presumption that gas is to be used regularly and withdrawn at more or less constant rate therefore gas holder needs to have only half the volume of estimated daily gas production. Thus for daily biogas production of $2 \mathrm{~m}^{3} / \mathrm{day}$, gasholder needs to have a capacity of only $1 \mathrm{~m}^{3}$. For a proper movement of drum, 5 inch gap was kept in between movable dome and inner wall of digester (Kumari et al., 2010). Therefore in total gasholder diameter was 10 inches (approx $25 \mathrm{~cm}$ ) smaller than digester diameter. Hence diameter of gasholder/dome was kept as $1.1 \mathrm{~m}$. The height of gasholder is thus given by;

Height of gasholder $=\frac{\text { Volume }}{\text { Area }}$

Height of gasholder $=\frac{1 \times 4}{\Pi \times\left(1.1^{2}\right)}$

Height of gasholder $=1.1 \mathrm{~m}$

Gasholder diameter $=1.1 \mathrm{~m}$

Gasholder height $=1.1 \mathrm{~m}$

\section{Results and Discussion}

Biogas plant of $2 \mathrm{~m}^{3}$ was developed for the codigestion of $25 \%$ SpBMS $+75 \%$ cow dung substrate. The designs of the various parts of developed biogas plant are shown in Figure 1,
2, 3, and 4. The developed plant in pictorial view is shown in Figure 5. The dome has provided with additional stirring mechanism to break the scum formation inside digester as shown in Figure 1. The developed plant was further evaluated continuously for 80 days by daily feeding a mixture of $12.5 \mathrm{~kg}$ of spent button mushroom substrate and $37.5 \mathrm{~kg}$ of fresh cowdung with $100 \mathrm{~kg}$ of water. $100 \mathrm{~kg}$ of water with $50 \mathrm{~kg}$ of selected substrate $(12.5$ $\mathrm{kg}$ SpBMS $+37.5 \mathrm{~kg}$ cow dung) was mixed daily to maintain $10 \%$ solid content of material.

The basic components of developed biogas plants are;

Digester or fermentation chamber,

Plant dome/Gas holder or gas storage chamber Inlet (pipe or tank),

Outlet (pipe or tank),

Mixing tank,

Gas outlet pipe.

Biogas produced from the developed plant was measured continuously for 80 days from the day it was fed with spent button mushroom substrate and cow dung mixture in the proportion of 1:3. The hydraulic retention time (HRT) of the modified biogas plant was 40 days, so the observations of produced biogas were recorded daily throughout two cycles of HRT (80 days). The observations were recorded from $4^{\text {th }}$ February, 2016 to $23^{\text {rd }}$ April, 2016. The volume of biogas generated was measured by using biogas flowmeter.

Figure 6 shows the relationship between the daily biogas production yield, daily biogas production at STP and substrate temperature with respect to days of biomethanation for codigestion of spent button mushroom substrate (SpBMS) and cowdung (CD) (25\% SpBMS+75\%CD) at feeding rate of $15.4 \mathrm{~kg}$ $\mathrm{dm} /$ day. 
Fig.1 Dome/gas holder of developed biogas plant

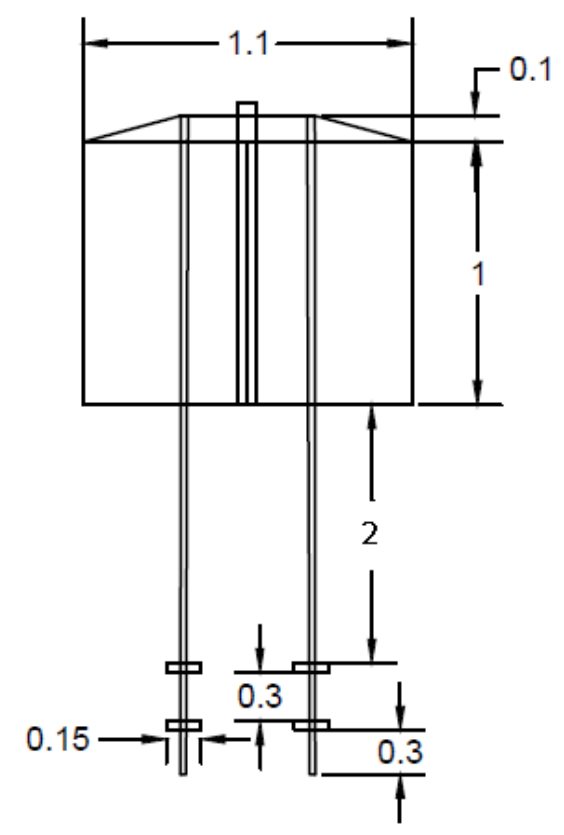

Fig.2 Digester of developed biogas plant

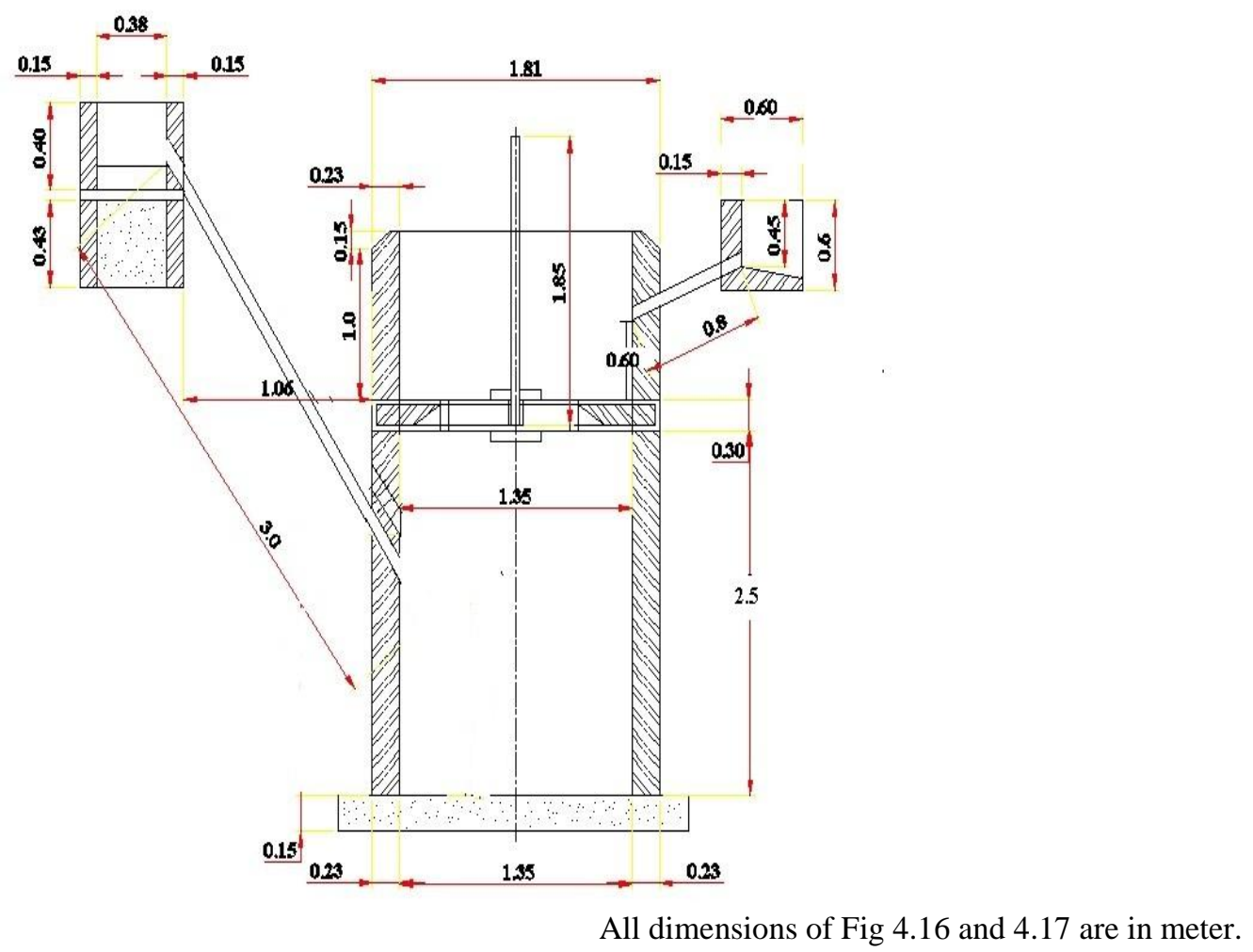


Fig.3 Top view of developed biogas plant

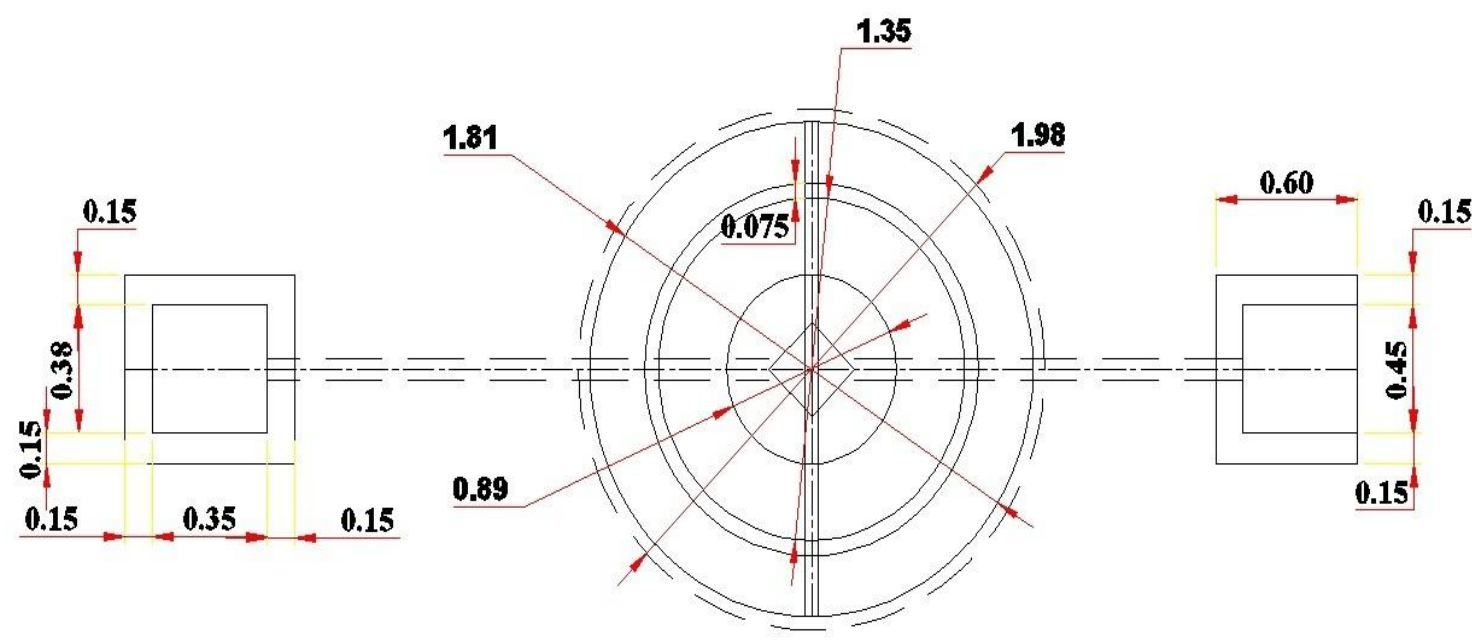

Fig.4 Design of central guide frame of biogas plant
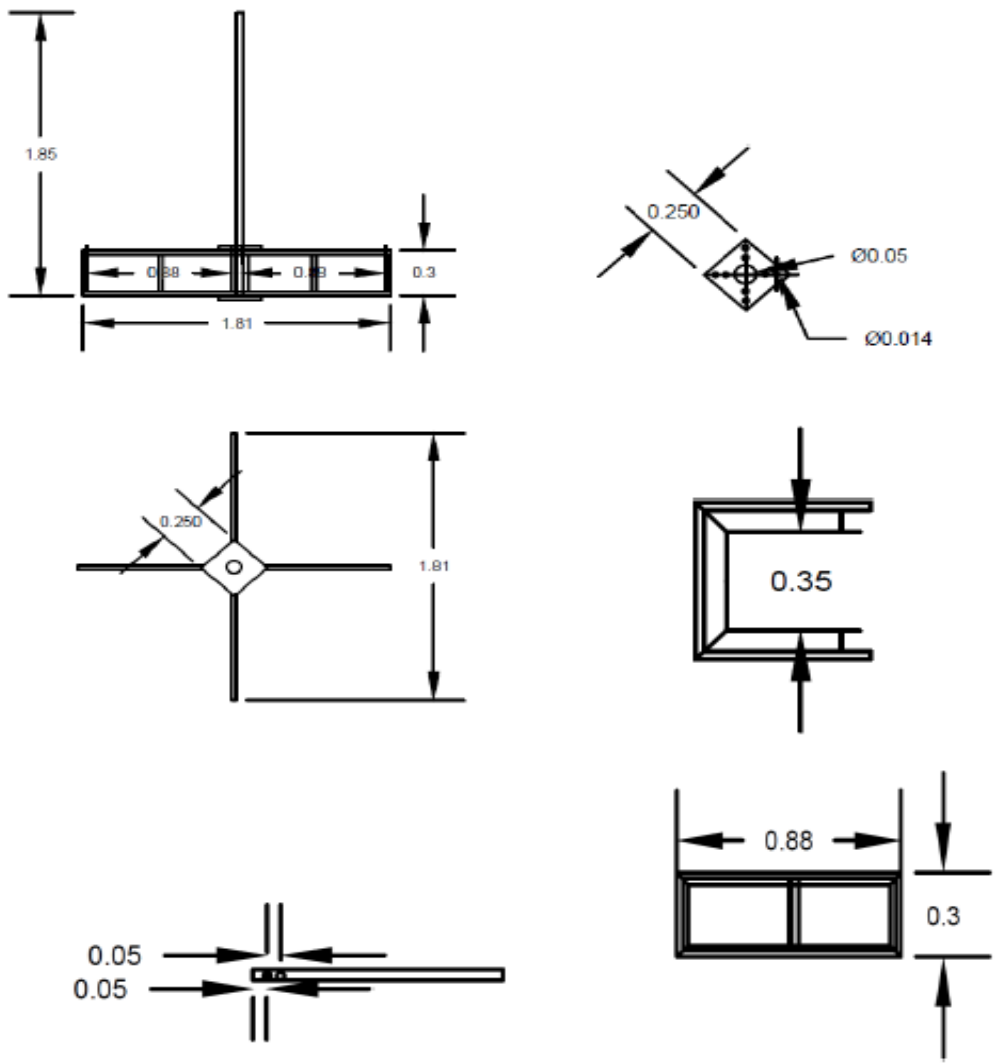

All dimensions of Fig 3 and 4 are in meter. 
Fig.5 Developed biogas plant for codigestion of spent button mushroom substrate and cow dung
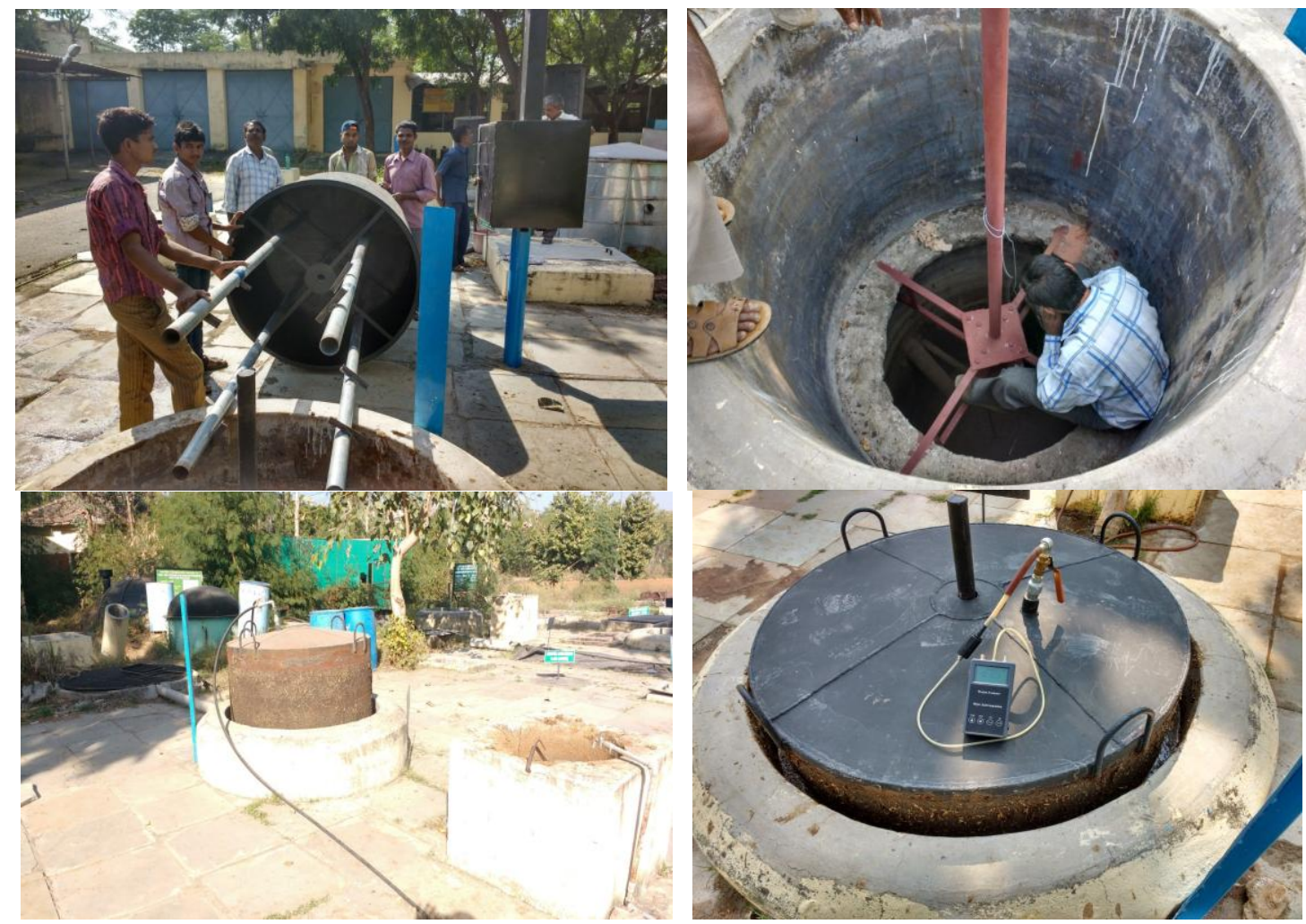

Fig.6 Biogas production in $\mathrm{m}^{3} /$ day from codigestion of spent button mushroom substrate and cow dung

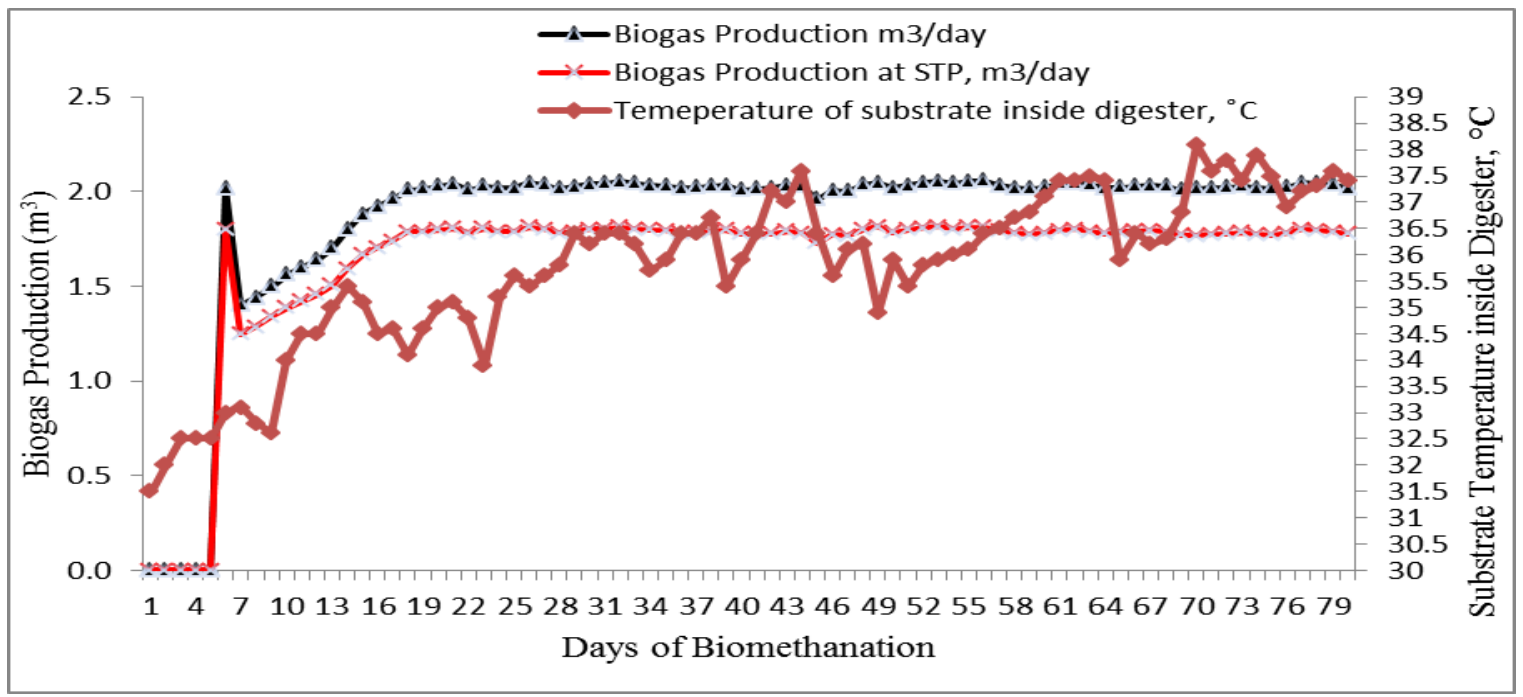

The average daily biogas production during 80 days of biomethanation period was observed as $1.852 \mathrm{~m}^{3} /$ day.
It was observed that biogas production was started from seventh day and biogas production rate became stable after fifteenth $\left(15^{\text {th }}\right)$ day of digestion process. The substrate temperature 
during anaerobic digestion of spent button mushroom substrate and cowdung was observed in the range of $31.5^{\circ} \mathrm{C}$ to $37.9^{\circ} \mathrm{C}$.

The observed substrate temperature indicates that the digester was operating in mesophilic temperature range. It has been reported that mesophilic methanogens are more active in the temperature range of $20-45^{\circ} \mathrm{C}$ and the biogas production reaches maximum when substrate temperature inside digester is maintained around $35^{\circ} \mathrm{C}$ (Zeeman et al., 1983).

Furthermore it has been also reported by Deublein and Steinhauser (2008) that at 30-35 ${ }^{\circ} \mathrm{C}$ substrate temperature, methanogens are more active.

\section{Acknowledgement}

Authors are highly thankful to Department of Renewable Energy Engineering, College of Technology and Engineering, Maharana Pratap University of Agriculture and Technology, Udaipur (Rajasthan), India for providing necessary facilities and financial support to carry out this research work.

\section{References}

Bisaria, R., Madan, M. and Mukhopadhyay, S.N. 1983. Production of biogas from residues from mushroom cultivation. Biotechnol Lett 5: 811-812.

Deublein, D., Steinhauser, A.2008. Biogas from waste and renewable sources: an introduction. Weinheim: WILEY-VCH Verlag GmbH \& Co. KGaA.

Fleming, R., Macalpine, M. and Sandy. 2006. Feasibility of using anaerobic digestion and composting to recover additional value from spent mushroom substrate. Report submitted to University of Guelph, Ridgetown campus, Ridgetown, ON, NOP, $2 \mathrm{CO}$.

Kumari, S., Wati, L. and Kapoor, K.K. 2010. Biogas production from spent oyster mushroom substrate. Haryana Agricultural University Journal of Research 40: 1-4.

Kumari, S., Wati, L., Kant, R., Chourasia, K. and Singh, U. 2013. Management of spent mushroom substrate through enrichment of biogas plant slurry. Trends in Biosciences 6: 589-591.

Lin, Y., Ge, X., and Li, Y. 2014. Solid State anaerobic codigestion of spent mushroom substrate with yard trimmings and wheat straw for biogas production. Bioresource Technology 169: 468-474.

Mehta, V., Gupta, J. K., and Kaushal, S.C. 1990. Cultivation of Pleurotus florida mushroom on rice straw and biogas production from spent straw. World journal of Microbiology and Biotechnology 6: 366-370.

Wendi, Q., Fuding, G., Chun, X.T., Lingzhi, H., Hubo, J. and Deqin, Z. 2014. Determination of biogas production potential of mushroom cultivation waste. Guizhou Agricultural Sciences 42:237239.

Zeeman G, Koster-Treffers ME, Halm HD. 1983. Anaerobic digestion of dairy cow slurry. In: European symposium on anaerobic waste water treatment. TNO Corporate Communication Department. 492-510.

\section{How to cite this article:}

Pradip Narale, Surendra Kothari and Nafisa Ali. 2018. Development of Improved Biogas Plant for Biomethanation of Spent Mushroom Substrate and Cow dung. Int.J.Curr.Microbiol.App.Sci. 7(04): 2429-2435. doi: https://doi.org/10.20546/ijcmas.2018.704.279 